\title{
WHICH THEORIES AND CONCEPTIONS DO PSYCHOANALYSTS AND PSYCHOANALYTIC PSYCHOTHERAPISTS CONSIDER HELPFUL IN THEIR PRACTICE DURING THE COVID-19 PANDEMIC UNFOLDING IN UKRAINE?
}

\author{
Mariana Velykodna ${ }^{1}$, Halyna Tsyhanenko ${ }^{2}$ \\ ${ }^{1}$ Ph.D., clinical psychologist, Senior Lecturer, Practical psychology department, Kryvyi Rih State Pedagogical \\ University, Kryvyi Rih, Ukraine; certified Psychoanalyst of Ukrainian Association of Psychoanalysis and European \\ Confederation of Psychoanalytic Psychotherapies, Kryvyi Rih (Ukraine) \\ ORCID ID: https://orcid.org/0000-0001-6269-793X \\ ${ }^{2}$ Ph.D., practical psychologist, Senior Researcher, Associate Professor, Ukrainian State Employment Service \\ Training Institute, Kyiv, Ukraine; member of Ukrainian Union of Psychotherapists, Kryvyi Rih (Ukraine) \\ ORCID ID: https://orcid.org/0000-0003-1950-157X
}

UDC: 159.964

\begin{abstract}
This paper presents the results of an anonymous survey of psychoanalysts and psychoanalytic psychotherapists $(\mathrm{n}=71)$ from different institutions, associations, and theoretical schools, which was conducted online after a month of lockdown in Ukraine due to the COVID-19 pandemic. According to the survey, one-third of the respondents adhered to their usual psychoanalytic theories and conceptions for reflecting on the phenomena they observed during the pandemic unfolding. Two-thirds of the practitioners admitted that they had been focusing or shifting toward certain conceptions in their theoretical thinking more than they used to. These theories were referring to the following two main issues: (1) how the psychic response to the COVID-19 pandemic and quarantine in each particular case can be explained and theorized on, and (2) how a psychoanalyst can deal with it through his or her own analytic stance and interventions. Practitioners tended to refer to the theoretical viewpoints of "Classic psychoanalysis", "Object relations", and the variety of particular one-time-mentioned theories of mourning, anxiety, trauma, defense mechanisms, manifestation of neurotic conflicts, Self issues, complexes, early traumatic experience, etc.
\end{abstract}

Keywords: COVID-19, pandemic, psychoanalysis, psychoanalytic psychotherapy, transference, countertransference.

Introduction. The tense situation of the COVID19 pandemic dictates to providers of psychological support and psychotherapy to change substantially their common format of practice, e.g. to conduct remote sessions (Inchausti \& et al., 2020; Perrin \& et al., 2020), to deal with chaotic schedules (Velykodna, Frankova, 2020), and to shift to urgent and educative interventions or even to suspend their practice (Velykodna, 2020; Tsyhanenko, Velykodna, 2020), etc. However, such observed phenomena may be less significant in those approaches for which working in person, a stable setting and slow, not rushed, processes are not as crucial as for psychoanalysts.
For the "pure gold of psychoanalysis" since S. Freud (1919) there had been a standard of meeting in person more than twice a week, using a couch, along with long-term and open -ended psychoanalysis, with a neutral and abstinent psychoanalyst and an adult analysand in his or her deepening regression. Nowadays, a number of psychoanalytic approaches have departed from this standard due to many reasons, e.g., expanding the range of patients to psychotic (Spotnitz, 2004), narcissistic (Kohut, 1985), borderline (Kernberg, 1967), i.e., so-called "nonneurotic" (Green, 1975), traumatized (Fonagy, 2010) ones, and even to "anti-analysands" (McDougall, 1972), as well

Address for correspondence, e-mail: editpsychas@gmail.com

Copyright: (C) Mariana Velykodna, Halyna Tsyhanenko

This is an Open Access journal, all articles are distributed under the terms of the Creative Commons Attribution-NonCommercial-ShareAlike 4.0 International (CC BY-NC-SA 4.0) License (http://creativecommons.org/licenses/by-nc-sa/4.0/), allowing third parties to copy and redistribute the material in any medium or format and to remix, transform, and build upon the material, provided the original work is properly cited and states its license. 
DOI (Issue): https://doi.org/10.31108/1.2020.6.8

as to just poor and vulnerable people who need short-term, affordable treatment (Gaztambide, 2012). Besides, psychoanalysis has consistently modified its method for children (Freud, 1937; Freud, Burlingham, 1943; Dolto, 2011; Klein, 1933; Morgenstern, 1937), adolescents (Dolto, 2012; Lesourd, 2013; Velykodna, Edelieva, 2020) and couples (Smadja, 2018). Some other modifications of the psychoanalytic technique were associated with new or developed theoretical approaches. The bright examples of such modification are Intersubjective (Stolorow, Brandchaft, Atwood, 1987) and Relational schools of psychoanalysis (Mitchell, 2009; Elise, 2019).

In spite of the rich history of the aforementioned changes and developments, we would venture to state that psychoanalysts were not prepared for further urgent modifications to conduct their practice during the pandemic and the limitations of the quarantine. Not in the sense of lack of technological tools or their own braveness to try a remote format or to make rearrangements on the setting, but in terms of the theoretical and ethical basis for such practice. Is this remote format of sessions still a psychoanalysis or a therapy? Are the analysand's troubles with finding a place, time, or money for his or her remote sessions during the lockdown just new manifestations of resistance or transference? Are the analysand's feelings and fears of the COVID-19 pandemic just copies of the other, previously experienced reactions or representatives of drives? What would be the best analytic stance for this crisis period? Would certain analysand benefit from such a format of sessions instead of suspending psychoanalysis for some time? Psychoanalysts are faced with the range of questions to which they have to find or invent their own responses. Fortunately, for many of these questions psychoanalytic associations have proposed their responses in the form of guidelines with general recommendations. However, a certain unique case or circumstances of a certain country may not be covered by them. That is why we believe it is important to study the available theories, conceptions, and ideas, which psychoanalysts and psychoanalytic psychotherapists considered helpful for practicing and dealing with this unexpected situation provoked by the COVID-19 pandemic.

The objective of this paper is to present psychoanalytic theories and conceptions which were especially helpful in practicing psychoanalysis and psychoanalytic psychotherapy in the context of the COVID -19 pandemic unfolding in Ukraine. These results are based on an anonymous online survey of Ukrainian psychoanalysts and psychoanalytic psychotherapists from different institutions, associations, and theoretical schools.

Analysis of current evidence. Psychoanalysts are discussing the impact of SARS-CoV-2 and quarantines on different aspects of social and individual life of the subject, and report their own clinical observations, referencing to and developing some previously formulated ideas. Some recent examples are as follows:

a) concepts of the fear of annihilation and fear of loss of the loved objects (Steel, 2020);

b) unconscious killing fantasies, which were manifested due to the COVID-19 crisis (Benvenuto, 2020);

c) "the viral uncanny" (in terms of S. Freud's "uncanny") as a severe experience, when something seemed both strangely familiar (being a repressed aspect of the subject) and frighteningly alien (Dodds, 2020);

d) unconscious meaning of the novel coronavirus as a signifier of contagion, a traumatic intrusion of the Real (Western, 2020);

e) regression, phantasmatically connected to the intrauterine stage, which activates archaic defensive mechanisms (Zangrilli, 2020);

f) de-libidinization of the analytic field (Elise, personal communication, 2020), which damages the libidinal vitality and creativity of an analytic couple (Elise, 2019);

g) patient's need in accepting the realistic, nonneurotic status of his or her fear and loss, associated with the COVID-19 (McWilliams, 2020);

h) symbolic specifics of providing sessions on the ZOOM platform, where the analysand needs to press the button "Leave Meeting", which signifies sessions as "meetings" and faces him or her with the topic of “endings" (Malater, 2020);

i) social psychic response to the COVID-19 with excessive paranoid, obsessive and phobic symptomatology seem to refer to the "return of the rejected", Freud's "Verwerfung" (Yuran, 2020).

This paper will focus on the theoretical ideas, which proved to be also helpful for practitioners in their 
own clinical work during the first month of lockdown in Ukraine.

Method. The anonymous online-survey was developed for Ukrainian practitioners in psychoanalysis and psychoanalytic psychotherapy. The study was reviewed and approved by the Local Ethics Committee of the Psychology Department of Ukrainian State Employment Service Training Institute (Kyiv, Ukraine). The survey was conducted after a month when the quarantine in the country had been imposed (on March, 16) to assess first observations and considerations of practitioners related to the period of uncertainty and the COVID-19 pandemic unfolding.

The respondents were members of various associations, working in different psychoanalytic approaches and having a range of professional status from candidates to supervisors.

From the 8 th to 15 th of April, 2020, the participants were asked via the Internet (i.e., through announcements in social networks and e-mails) to answer a number of questions anonymously in an online form, and were also informed that the aim of the survey was this research. Consents for participating in the survey, for gathering the personal data, and for publishing the results were also signed via the Internet before filling in the form of the survey.

The survey was developed as an anonymous questionnaire written in Ukrainian with open and closed questions. Atop the survey was a short motivation letter, where the goals of the research were presented, along with a consent signature.

The following groups of questions were proposed:

1) general professional data: method of practicing (psychoanalysis, psychoanalytic psychotherapy, or both); years of practical experience; membership in psychoanalytic associations; status of the specialist (candidate, psychoanalyst, training psychoanalyst, supervisor); types of patients the practitioner typically works with (adults, adolescents, children, groups);

2) current professional data: whether the respondent has kept or suspended the practice due to the quarantine; any increase or decrease in the number of analysands and sessions per week;

3) theoretical considerations from practicing during the quarantine: helpful theories, approaches, and conceptions for the analysis of new topics, states, and transference-countertransference dynamics on the sessions related to COVID-19.

Data analysis of this study included descriptive statistics, non-parametric comparison by $\chi 2$ for frequencies analysis, and Spearman rank one-tail and two-tail correlation using IBM SPSS Statistics software. Multiple response analysis was used for the variable with patients' description.

Results. The responses were obtained $(n=71)$ from certified psychoanalysts and psychoanalytic psychotherapists $(63,4 \%)$, training psychoanalysts $(7 \%)$, supervisors $(9,9 \%)$ and candidates for psychoanalytic certification, who practiced under supervision $(19,7 \%)$, with work experience from 1 to 25 years $(M=9,45$, $\mathrm{SD}=6,19$, mode $\mathrm{Mo}=10$, median $\mathrm{Me}=9$ ). Among them were male $(19,7 \%)$ and female $(78,9 \%)$ respondents; 1 practitioner indicated their sex as "other". Most of survey participants $(87,3 \%)$ marked psychoanalytic therapy as the method they were practicing, while 53,5\% practiced psychoanalysis. Thus, $40,8 \%$ were practicing both methods.

There was a possibility to choose multiple responses to the question about the common category of analysants. As a result, psychoanalysts and psychoanalytic psychotherapists have adults $(98,6 \%)$, adolescents $(43,7 \%)$, children (26,8\%), and groups $(23,9 \%)$ among their analysands.

The majority (91,5\%) of survey participants admitted their membership in one or more psychoanalytic associations (Table 1).

$83,1 \%$ of survey respondents stated that they continued practicing during the quarantine. From the group of practicing respondents $(n=59$ as $100 \%)$, one third $(30,5 \%)$ answered they adhered to their usual psychoanalytic theories and conceptions for speculating about any phenomenon they observed during the study period.

Therefore, two-thirds of the practitioners admitted that they had been focusing or shifting toward certain conceptions in their theoretical thinking more than they used to. Interestingly, it was not associated with the years of their experience $(\mathrm{r}=0,18, \mathrm{p}=0,08)$ and certification status $\left(\chi^{2}=1,35, p=0,72\right)$. 


\section{Distribution of membership in psychoanalytic associations}

\begin{tabular}{|l|c|c|}
\hline Institution of membership & Responses (n) & Responses (\%) \\
\hline Ukrainian Association of Psychoanalysis & 23 & 32,4 \\
\hline Ukrainian Union of Psychotherapists & 23 & 32,4 \\
\hline Ukrainian Psychoanalytic Union & 17 & 23,9 \\
\hline European Confederation of Psychoanalytic Psychotherapies & 17 & 23,9 \\
\hline Ukrainian Confederation of Psychoanalytic Psychotherapies & 14 & 19,7 \\
\hline International Psychoanalytic Association & 4 & 5,6 \\
\hline European Federation of Psychoanalytic Psychotherapies & 4 & 5,6 \\
\hline Union of Psychologists and Psychotherapists of Ukraine & 2 & 2,8 \\
\hline Association of Psychotherapists and Psychoanalysts of Ukraine & 2 & 1,4 \\
\hline Group of Freud Field in Ukraine & 2 & 1,4 \\
\hline
\end{tabular}

Overall, the surveyed practitioners made 87 into categories based on their authors and general approach, mentions of such theories in their written responses. i.e. psychoanalytic school (Table 2). Content-analysis of the responses showed noticeable diversity of mentioned theories and conceptions (54 conceptions among 87 mentions). Thus, finding a way to summarize them into categories or groups turned out to be a challenge. Firstly, we distributed the mentioned theories
As we see from Table 2, the most frequently mentioned categories were "Classic psychoanalysis" $(39,61 \%)$, "Object relations" $(25,3 \%)$, the variety of particular theories from Jungian to subjective and relational schools $(27,6 \%)$, and, surprisingly, non-analytic theories and concepts $(8 \%)$. To be more illustrative, we

Table 2

\section{Categories and content units of the mentioned theories and conceptions}

\begin{tabular}{|c|c|c|c|c|}
\hline No & Category & Content unit & Mentions (n) & Mentions (\%) \\
\hline 1 & \multicolumn{2}{|l|}{ Psychoanalytic theories } & & \\
\hline \multirow[t]{9}{*}{1.1} & Classic psychoanalysis & classic psychoanalytic theory & 4 & \\
\hline & Overall, the & personal analysis & 2 & \\
\hline & Freud & Freud & 7 & \\
\hline & & mass psychology & 3 & \\
\hline & & mourning and melancholia & 2 & \\
\hline & & neurosis & 2 & \\
\hline & & trauma theory & 2 & \\
\hline & & anxiety & 1 & \\
\hline & & defense mechanisms & 1 & \\
\hline
\end{tabular}


ISSN 2414-0023 (Print)

ISSN 2414-004X (Online)

DOI (Issue): https://doi.org/10.31108/1.2020.6.8

Volume 6 Issue 82020

\begin{tabular}{|c|c|c|c|c|}
\hline & & narcissism & 1 & \\
\hline & & Oedipus complex & 1 & \\
\hline & & obsessive neurosis & 1 & \\
\hline & & rationalization & 1 & \\
\hline & & totem and taboo & 1 & \\
\hline & Freudians & Adler & 1 & \\
\hline & & Ferenczi & 1 & \\
\hline & & Lacan & 3 & \\
\hline & Total 1.1 & & 34 & $39,1 \%$ \\
\hline 1.2 & Object relations & theories of object relations & 7 & \\
\hline & Klien & Klien & 3 & \\
\hline & & projective identification & 2 & \\
\hline & & splitting & 1 & \\
\hline & & persecutory anxiety & 1 & \\
\hline & Winnicott & Winnicott & 1 & \\
\hline & & "good enough mother" & 1 & \\
\hline & & holding & 1 & \\
\hline & Kernberg & Kernberg & 2 & \\
\hline & & affect theory & 1 & \\
\hline & & aggression & 1 & \\
\hline & & fixation on trauma & 1 & \\
\hline & Total 1.2 & & 22 & $25,3 \%$ \\
\hline 1.3 & Other particular theories & & & \\
\hline & Horney & Horney & 3 & \\
\hline & & principles of safety and satisfaction & 1 & \\
\hline & & fear and anxiety & 1 & \\
\hline & Yung & Yung's analytic approach & 2 & \\
\hline & Bion & Bion & 2 & \\
\hline & & containing & 2 & \\
\hline & Bollas & Bollas & 1 & \\
\hline & & transformational object & 1 & \\
\hline & & creating the analytic third - a fantasy & 1 & \\
\hline & Green & Green & 1 & \\
\hline & & conception of the "negative" & 1 & \\
\hline & Kohut & Kohut's self theory & 1 & \\
\hline & Attachment theory & attachment theory & 1 & \\
\hline & Smadja & self-soothing techniques & 1 & \\
\hline & Ego theories & Hartman's concept of "conflict-free sphere of ego functioning" & 1 & \\
\hline & Existential approach & Binswanger's existential approach & 1 & \\
\hline & $\begin{array}{l}\text { Models of experience from early } \\
\text { childhood }\end{array}$ & deprivation & 1 & \\
\hline & & separation & 1 & \\
\hline & Subject-oriented approach & Rozhdestvensky's subject-oriented approach & 1 & \\
\hline & Total 1.3 & & 24 & $27,6 \%$ \\
\hline & Total 1 & & 80 & $92 \%$ \\
\hline 2 & Non-analytic theories and methods & & & \\
\hline & & Kubler-Ross's theory of mourning & 2 & \\
\hline & & cognitive theories & 1 & \\
\hline & & stress management & 1 & \\
\hline & & techniques of stabilization & 1 & \\
\hline & & work with (external) reality & 1 & \\
\hline & & Yalom's existential approach & 1 & \\
\hline & Total 2 & & 7 & $8 \%$ \\
\hline Total & & & 87 & $100 \%$ \\
\hline
\end{tabular}


DOI (Issue): https://doi.org/10.31108/1.2020.6.8

have created Figure 1, which shows the distribution of the aforementioned categories.

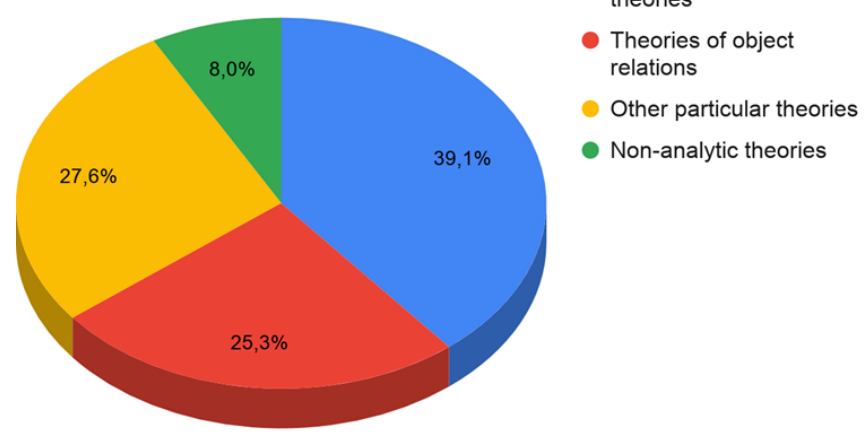

Figure 1. Distribution of the most frequently mentioned theories

In an attempt to find a more informative way of data analysis, we tried to systematize the mentioned conceptions by their key references to a certain phenomenon, process, or issue, i.e. "what do these theories talk about?". For this purpose, we ignored the mentioned names and theoretical schools, therefore, we analyzed 39 content units with 50 mentions in total (Table 3 ).
Total

As a result, 5 key references were obtained (Figure 2):

1) to the theories and conceptions which describe and explain individual psychic response to the pandemic and quarantine, i.e., anxiety, fear, mourning, mechanisms of defense and ways of coping, etc;

2) to the theories and conceptions which describe and explain social psychic response, i.e., "mass pandemic psychology";

3) to the theories and conceptions which theorize on some particular issues of analyzants manifested by the current situation, i.e., manifestation of neurotic conflicts, Self issues, complexes, early trauma, etc;

4) to practical recommendations and their theoretical bases about specific aspects of keeping an analytic stance, e.g., through containing, holding, transforming, own analysis, etc;

4) to certain interventions, both analytic (approaches) and non-analytic (e.g., cognitive methods, techniques of stabilization, stress management).

Discussion. First of all, some specifics of the Table 3

\section{Key references of the mentioned theories and conceptions}

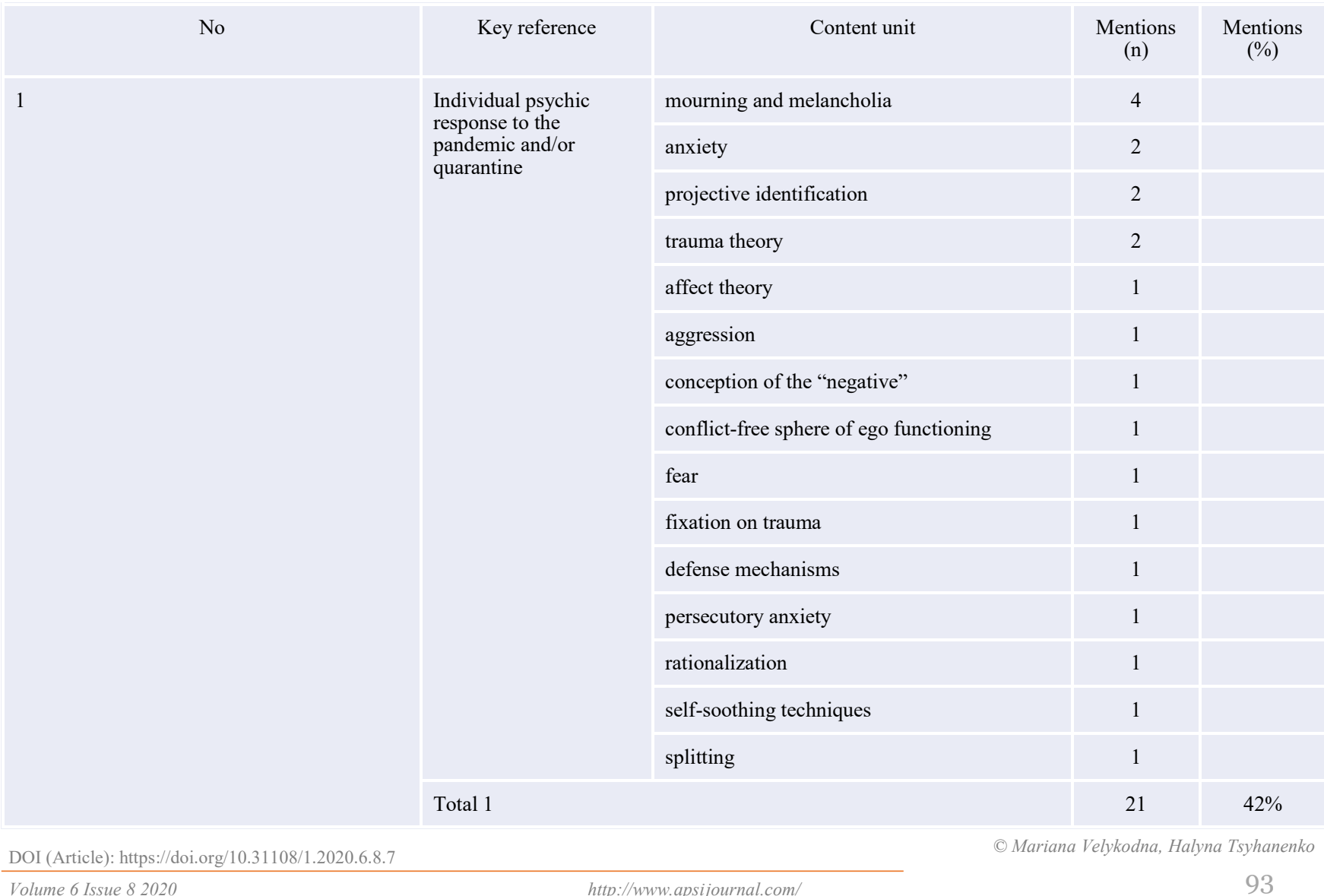


2
Social psychic response to the pandemic and/or quarantine

Total 2

Analytic stance

Total 3

Interventions

Total 4

Manifested issues

Total 5

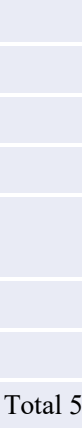

\begin{tabular}{|l|l|}
\hline mass psychology \\
\hline totem and taboo \\
\hline
\end{tabular}

containing

personal analysis

attachment

creating the analytic third - a fantasy

"good enough mother"

holding

being a transforming object

existential approaches

cognitive interventions

techniques of stabilization

stress management

subject-oriented approach

work with (external) reality

Jungian approach

$16 \%$

deprivation

neurosis

obsessive neurosis

Oedipus complex

narcissism

conflict between principles of safety and satisfaction

Self issues

separation

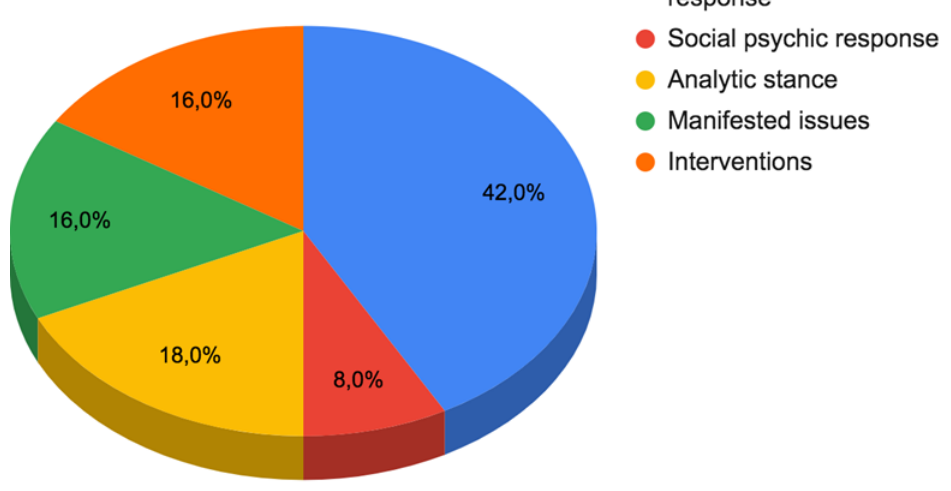

Individual psychic response

Social psychic response

Analytic stance

Manifested issues

Interventions

Figure 2. Distribution of the most frequently mentioned key references

sample need to be commented on. The gender distribution of the surveyed psychoanalysts ( $78,9 \%$ females) is not surprising, as it corresponds with the data obtained from studies on psychotherapists from the Czech Republic, Slovakia, and Germany $(77,8 \%$ females; Humer \& et al., $2020)$, Croatia $(88,6 \%$ females), other countries of South- 
Eastern Europe (89,2\% females) in Balkan region (Bagarić, Jokić-Begić, 2020), as well as on psychologists and psychotherapists from Ukraine (90,3\% females; Velykodna, Frankova, 2020). It may describe some gender asymmetry in psychoanalytic practice and in psychological occupations in general, typical for this region.

The sample size may look small in comparison to common or expected samples for nationwide surveys for psychological and psychotherapy practitioners. However, there are at least two reasons for it. Firstly, there are not many psychoanalysts and psychoanalytic psychotherapists in Ukraine. For example, on the website of the Ukrainian Association of Psychoanalysis (ECPP national branch) only 27 people are listed as certified psychoanalysts, training analysts or supervisors, whilst 9 are listed as practicing "alienation" and some evident or latent splits in psychoanalytic society, recently described by M. L. Ellis (2020); representatives of other associations might have been merely less enthusiastic to participate in a research conducted by "strangers" or "enemies".

Analyzing the aforementioned 5 categories of key references from Table 3 , we would conclude that $2 / 3$ of the surveyed psychoanalysts (69,5\%) and psychoanalytic psychotherapists in general are concerned about two main issues (Table 4).

Thus, the most helpful theories and conceptions for the surveyed respondents were those which can respond to these two questions. These mainly were theoretical viewpoints of "Classic psychoanalysis" (39,61\%), "Object relations" $(25,3 \%)$, and the variety of particular almost one-

Table 4

\section{The main issues which the mentioned theories and conceptions are referring to}

$\begin{array}{llll}\text { 1. How can the psychic response to the COVID-19 2. How can a psychoanalyst deal with it through his or her } & \text { 2. }\end{array}$ pandemic and quarantine in a particular case be explained and theorized on?

Category "Individual psychic response to the COVID-19 pandemic or quarantine" $(42 \%)$

Category "Social psychic response to the COVID-19 Category "Interventions" (16\%) pandemic or quarantine" $(8 \%)$

Category "Manifested issues" (16\%)

$$
66 \% \text { in total }
$$

candidates for certification (i.e., psychoanalytic counselors). The website of the Ukrainian Union of Psychotherapists (EAP national branch) provides information about 98 certified psychoanalysts, training analysts, and supervisors. The website of the Ukrainian Psychoanalytic Society (united IPA member from Ukraine) provides the visitors with a list of 25 psychoanalysts, training analysts, supervisors, and candidates. The second reason may be associated with the fact that the most frequently mentioned associations of membership are those of which the authors of this paper are members, too. Although we tried to share the announcement of the survey to a wider group of psychoanalysts and psychoanalytic psychotherapists, perhaps it was still easier to reach our colleagues. At the same time, it may also refer to Category "Analytic stance" (18\%) own analytic stance and interventions?

$34 \%$ in total

time-mentioned theories $(27,6 \%)$. To answer the first question, the practitioners were referring to the various theories of mourning, anxiety, trauma, certain mechanisms of defense and coping, as well as to conceptions for some partial issues of analysands manifested due to the current circumstances, such as manifestation of neurotic conflicts, Self issues, complexes, early traumatic experience, etc. As for the second question, the psychoanalysts referred to some conceptions which were valuable for supporting their analytic stance and for certain interventions, e.g., the significance of their own analysis, as well as containing, holding and transforming of the analysand's material. Some surveyed practitioners mentioned psychoanalytic approaches which they considered helpful these days. Interestingly, $8 \%$ of psychoanalysts and psychoanalytic 
DOI (Issue): https://doi.org/10.31108/1.2020.6.8

psychotherapists admitted that they had familiarized themselves with some non-analytic theories and concepts during this period, such as techniques of stress-management or stabilization. This also corresponds with the current position in psychotherapy, which claims that it is necessary to study which approach and setting will optimally serve the needs of people during the COVID-19 pandemic (Swartz, 2020). At the same time, it may be interpreted as the evidence of the lack of psychoanalytic theories or interventions on some important phenomena that occur during the real traumatizing and depriving period due to the pandemic unfolding. However, this hypothesis needs to be studied separately.

We believe it to be significant that the observed increased focus or shift toward a certain theory was not associated with the years of their experience and certification status. It raises the question of the influence of personality (including psychoanalyst's own unconsciousness), predominant approach, or theoretical school, which was impossible to study in this research. Besides, it seems obvious that we could have obtained more detailed responses if we had chosen the format of semistructured interviews rather than a survey. However, in that case, we could have lost the credibility of the answers. Moreover, it would have been extremely difficult to conduct semi-structured interviews in the context of allUkrainian lockdown.

Conclusions. The unavoidable tense situation of the COVID-19 pandemic dictates psychoanalysts to face with the range of questions, to which they have to find or invent their own responses. To some of these questions associations of phychoanalysts have formulated their clear guidelines. However, this study is focused on early weeks (less than a month) of COVID-19 pandemic unfolding, thus, a period of uncertainty in Ukraine. As M. L. Ellis (2020) truthfully formulated: "attention to our own and to our colleagues' vulnerabilities is generative of productive, creative and mutually enhancing professional relationships" (p. 124). We believe it important to study all the processes which psychoanalysts observe and theorize on during the COVID-19 pandemic.

Among the surveyed psychoanalysts who continued practicing during the quarantine, around twothirds admitted that they had been focusing or shifting toward certain conceptions in their theoretical thinking more than they used to, which did not correlate with their work experience or certification status. The obtained data content analysis has shown that these theories were referring to two main issues on (1) how the psychic response to the COVID-19 pandemic and quarantine in a certain case can be explained, and (2) how a psychoanalyst can deal with it through his or her own analytic stance and interventions. Practitioners were referring to the theoretical viewpoints of "Classic psychoanalysis", "Object relations", and the variety of particular theories, such as conceptions of mourning, anxiety, trauma, certain defense mechanisms and coping strategies, manifestation of neurotic conflicts, Self issues, complexes, early traumatic experience, etc. Besides, psychoanalysts noted some valuable conceptions for supporting their analytic stance and for certain interventions, e.g., the significance of their own analysis, as well as containing, holding, and transformation of analysand's material. An unexpected finding was the fact that $8 \%$ of psychoanalytic practitioners admitted they were focused on some non-analytic theories and concepts during their practice in the context of the COVID-19 pandemic, such as cognitive techniques of stress-management or stabilization. This may be interpreted both in terms of psychotherapy integration in order to obtain better results and as the evidence of lack of psychoanalytic theories or interventions for some important phenomena which take place during the real traumatizing and depriving periods like the pandemic unfolding.

\section{References:}

Bagarić, B., Jokić-Begić, N. (2020). Measuring therapists' attitudes toward integration of technology in psychotherapy and predicting their use of technology. Journal of clinical psychology. 2020; 1-22. doi: $10.1002 /$ jclp.22967

Benvenuto, S. (2020). The virus and the unconscious. My Diary. European Journal of Psychoanalysis. Issue "Psychoanalysts Facing Coronavirus". Date of access 05/02/2020. Available at: https:// www.journal-psychoanalysis.eu/the-virus-and-the-unconsciousmy-diary/

Binswanger, L. (1963). Being-in-the-world: Selected papers of Ludwig Binswanger.

Bollas, C. (1979). The transformational object. International Journal of Psychoanalysis, (60), 97-107. 
DOI (Issue): https://doi.org/10.31108/1.2020.6.8

Dodds, J. (2020). Elemental Catastrophe: Ecopsychoanalysis and the Viral Uncanny of COVID-19. Stillpoint: Digital Magazine in the Eye of the Storm, Issue 004 (Apocalypse). Date of access 05/03/2020. Available at: https://stillpointmag.org/articles/ elemental-catastrophe-ecopsychoanalysis-and-the-viraluncanny-of-covid-19/

Dolto, F. (2011). La cause des enfants. Robert Laffont.

Dolto, F. (2012). La cause des adolescents. Robert Laffont.

Elise, D. (2019). Creativity and the Erotic Dimensions of the Analytic Field. Routledge.

Ellis, M. L. (2020). Dissenting colleagues; power, alienation, vulnerability, Psychodynamic Practice, 26:2, 124-135, doi: $10.1080 / 14753634.2020 .1745677$

Fonagy, P. (2010). Attachment, trauma, and psychoanalysis: Where psychoanalysis meets neuroscience. In Early Development and its Disturbances. Clinical, Conceptual and Empirical Research on ADHD and other Psychopathologies and its Epistemological Reflections. Ed. J. Canestri, M. Leuzinger-Bohleber, M. Target. London, Routledge.

Freud, A., Burlingham, D. T. (1943). War and children.

Freud, A. (1937). The Ego and the Mechanisms of Defense. (The International Psychoanalytical Library, No. 30.)

Freud, S. (1955). Lines of advance in psychoanalytic therapy. In L. Strachey (Ed. \& Trans.). The standard edition of the complete psychological works of Sigmund Freud (Vol. 17, pp. 157-168). London: Hogarth Press. (Originally published in 1919.)

Gaztambide, D. J. (2012). “A Psychotherapy for the People" Freud, Ferenczi, and Psychoanalytic Work with the Underprivileged. Contemporary Psychoanalysis, 48(2), 141-165. doi: 10.1080/00107530.2012.10746495

Green, A. (1975). The analyst, symbolization and absence in the analytic setting (on changes in analytic practice and analytic experience) In memory of D. W. Winnicott. International Journal of Psychoanalysis, 56:1-22.

Hartmann, H. (1958). The conflict-free ego sphere. Ego Psychology and the Problem of Adaptation. IUP. New York.

Horney, K. (1991). Neurosis and human growth: The struggle toward selfrealization. WW Norton \& Company.

Humer, E., Pieh, C., Kuska, M., Barke, A., Doering, B. K., Gossmann, K., ... \& Probst, T. (2020). Provision of Psychotherapy during the COVID-19 Pandemic among Czech, German and Slovak Psychotherapists. International Journal of Environmental Research and Public Health, 17(13), 4811. doi:10.3390/ ijerph17134811

Inchausti, F., MacBeth, A., Hasson-Ohayon, I., \& Dimaggio, G. (2020). Telepsychotherapy in the age of COVID-19: A commentary. Journal of Psychotherapy Integration, 30(2), 394-405. doi: 10.1037/int0000222
Volume 6 Issue 82020

Jung, C. G. (1959). The basic writings of CG Jung.

Kernberg, O. (1967). Borderline personality organization. Journal of the American psychoanalytic Association, 15(3), 641-685.

Klein, M. (1933). The psychoanalysis of children. The Sociological Review, 25(3), 296-298.

Kohut, H. (1985). Self psychology and the humanities: Reflections on a new psychoanalytic approach. WW Norton.

Kübler-Ross, E., \& Kessler, D. (2005). On grief and grieving: Finding the meaning of grief through the five stages of loss. Simon and Schuster.

Lesourd, S. (2013). La construction adolescente. Eres.

Malater, E. (2020). The Logical Time of Ending a ZOOM Session as a Metaphor for the Terror of the Current Situation. European Journal of Psychoanalysis. Issue "Psychoanalysts Facing Coronavirus". Date of access 05/02/2020. Available at: https:// www.journal-psychoanalysis.eu/the-logical-time-of-ending-azoom-session-as-a-metaphor-for-the-terror-of-the-currentsituation/

McDougall, J. (1972). The anti-analysand in analysis. In Ten years of psychoanalysis in France. New York: International Universities Press, 1980 .

McWilliams, N. (2020). Psychotherapy in a Pandemic. Psicoanalisi applicata alla Medicina, Pedagogia, Sociologia, Letteratura ed Arte. Date of access 05/02/2020. Available at: http:// web.tiscali.it/cispp/mcwilliamsPANDEMIC.htm

Mitchell, S. A. (2009). Relational concepts in psychoanalysis. Harvard University Press.

Morgenstern, S. (1937). Psychanalyse infantile: symbolisme et valeur clinique des créations imaginatives chez l'enfant. Ed. Denoël.

Perrin, P. B., Rybarczyk, B. D., Pierce, B. S., Jones, H. A., Shaffer, C., \& Islam, L. (2020). Rapid telepsychology deployment during the COVID-19 pandemic: A special issue commentary and lessons from primary care psychology training. Journal of Clinical Psychology, 76(6), 1173-1185. doi: 10.1002/jclp.22969

Rozhdestvensky, D. (2017). Psychoanalysis modern. Subject-oriented approach. Ergo, Izhevsk. [In Russian]

Smadja, C. (2001). La vie opératoire: études psychanalytiques. Presses universitaires de France.

Smadja, É. (2018). Le couple et son histoire. Presses universitaires de France.

Steele, H. (2020). COVID-19, Fear and the Future: an attachment perspective. Clinical Neuropsychiatry, 17(2).

Stolorow, R. D., Brandchaft, B., \& Atwood, G. E. (1987). Psychoanalytic treatment: An intersubjective approach.

Swartz, H. A. (2020). The Role of Psychotherapy During the COVID-19 Pandemic. American journal of psychotherapy. 73(2):41-42. doi: 10.1176/appi.psychotherapy.20200015 
DOI (Issue): https://doi.org/10.31108/1.2020.6.8

The Ukrainian Association of Psychoanalysis. Website. Date of access 09/08/2020. Available at: http://pa-uap.org/

The Ukrainian Psychoanalytic Society. Website. Date of access 09/08/2020. Available at: https://psy-a.in.ua/

The Ukrainian Union of Psychotherapists. Website. Date of access 09/08/2020. Available at: https://usp.community/register

Tsyhanenko, H., Velykodna, M. (2020). Providing psychological assistance to vulnerable populations during and after quarantine due to the COVID-19 pandemic. Kyiv, Kryvyi Rih. Publisher Roman Kozlov.

Velykodna, M. (2020). Models and methods of psychological support during the COVID-19 pandemic: the foreign experience. Psychological Journal. Volume 6, Issue 4. P. 229-237. doi: 10.31108/1.2020.6.4.19

Velykodna, M., Edelieva, K. (2020). The issue of adolescence in psychoanalysis: theory, techniques and ethics of practical work. Habitus. Issue 12, Vol. 2., 11-17.

Velykodna, M., Frankova I. (2020). Psychological and psychotherapeutic assistance during the COVID-19 pandemic: current challenges. Psychosomatic Medicine and General Practice. Vol. 5, Issue 1, doi: 10.26766/PMGP.V5I1.213

Western, S. (2020). Covid-19: An intrusion of the Real The unconscious unleashes its Truth. Electronic Essay on Academia.edu. Date of access 05/02/2020. Available at: https:// www.academia.edu/42201252/Covid-

19_An_intrusion_of_the_Real_The_unconscious_unleashes_its - Truth

Yalom, I. D. (1980). Existential Psychotherapy.

Yuran, A. On tendencies manifested by COVID-19. Psy.Media. Date of access 05/08/2020. Available at: https://psy.media/aiten-yurano-viruse/

Zangrilli, Q. (2020). Coronavirus and Psychic Regression. Psicoanalisi e Scienza. Date of access 05/03/2020. Avialable at: https:// www.psicoanalisi.it/english/205936/
Volume 6 Issue 82020

\section{Mariana Velykodna}

Ph.D., clinical psychologist, Senior Lecturer, Practical psychology department, Kryvyi Rih State Pedagogical University, certified Psychoanalyst of Ukrainian Association of Psychoanalysis and European Confederation of Psychoanalytic Psychotherapies, Kyiv (Ukraine)

\section{Halyna Tsyhanenko}

Ph.D., practical psychologist, Senior Researcher, Associate Professor, Ukrainian State Employment Service Training Institute, member of Ukrainian Union of Psychotherapists, Kyiv (Ukraine)

\section{WHICH THEORIES AND CONCEPTIONS DO PSYCHOANALYSTS AND PSYCHOANALYTIC PSYCHOTHERAPISTS CONSIDER HELPFUL IN THEIR PRACTICE DURING THE COVID-19 PANDEMIC UNFOLDING IN UKRAINE?}

\section{ABSTRACT}

The unavoidable tense situation of the COVID-19 pandemic dictates psychoanalysts to face with the range of questions, to which they have to find or invent their own responses. To some of these questions associations have formulated their clear guidelines. However, a certain unique case and circumstances of a certain country may not be covered by them. We believe it important to study all the processes which psychoanalysts observe and theorize on during the COVID-19 pandemic. This paper presents the results of an anonymous survey of psychoanalysts and psychoanalytic psychotherapists $(n=71)$ from different institutions, associations and theoretical schools, which was conducted online after a month of lockdown in Ukraine to assess first observations and considerations of practitioners, which were related to the period of uncertainty and the COVID-19 pandemic unfolding.

Among the surveyed psychoanalysts who continued practicing during the quarantine, around twothirds admitted that they had been focusing or shifting toward certain conceptions in their theoretical thinking more than they used to, which did not correlate with their experience or certification status. The obtained data content analysis has shown that these theories were referring to the following two main issues on (1) how the psychic response to the COVID-19 pandemic and quarantine in a particular case can be explained, and (2) how a psychoanalyst can deal with it through his or her own analytic stance and interventions. Practitioners were referring to the theoretical viewpoints of "Classic psychoanalysis", "Object relations", and the variety of particular theories, such as conceptions of 
mourning, anxiety, trauma, defense mechanisms and coping, manifestation of neurotic conflicts, Self issues, complexes, early traumatic experience, etc. Besides, psychoanalysts noted some valuable conceptions for supporting their analytic stance and for certain interventions, e.g., the significance of their own analysis, as well as containing, holding and transforming the analysand's material. An unexpected finding was that $8 \%$ of psychoanalytic practitioners admitted that they were focused on some non-analytic theories and concepts during their practice in the context of the COVID-19 pandemic, such as cognitive techniques of stress-management or stabilization. This may be interpreted both in terms of psychotherapy integration in order to obtain better results, as well as the evidence of lack of psychoanalytic theories or interventions for some important phenomena which take place during the real traumatized and depriving periods like the pandemic unfolding.

Keywords: COVID-19, classic psychoanalysis, object relations, pandemic, psychoanalysis, psychoanalytic psychotherapy.

\section{Марьяна Великодная}

Кандидат психологических наук, клинический психолог, старший преподаватель кафедры практической психологии Криворожского государственного педагогического университета, сертифииированный психоаналитик Украинской ассочиаџии психоанализа Европейской конфедерации психоаналитических психотерапий, г. Киев (Украина)

\section{Галина Циганенко}

Кандидат психологических наук, практический психолог, стариий научный сотрудник, дочент кафедры психологии Института подготовки кадров государственной службы занятости Украины, г. Киев (Украина)

\section{КАКИЕ ТЕОРИИ И КОНЦЕПЦИИ ПСИХОАНА- ЛИТИКИ И ПСИХОАНАЛИТИЧЕСКИЕ ПСИХО- ТЕРАПЕВТЫ СЧИТАЮТ ЦЕННЫМИ В СВОЕЙ ПРАКТИКЕ ВО ВРЕМЯ РАЗВОРАЧИВАЮЩЕЙ- СЯ ПАНДЕМИИ СОVID-19 В УКРАИНЕ?}

\section{АННОТАЦИЯ}

Неизбежная напряженная ситуация из-за пандемии COVID-19 сталкивает психоаналитиков с различными вопросами, на которые приходится находить или изобретать собственные ответы. К некоторым из этих вопросов психоаналитические ассоциации сформулировали четкие указания. Однако определенный уникальный случай и обстоятельства конкретной страны могут не охватываться ними. Авторы статьи считают, что важно исследовать те процессы, которые наблюдают и теоретизируют психоаналитики во время пандемии COVID-19. В этой статье представлены результаты анонимного опроса психоаналитиков и психоаналитических психотерапевтов $(\mathrm{n}=71)$ из различных учреждений, ассоциаций и теоретических школ, проведенного онлайн через месяц карантина в Украине, для оценки первых наблюдений и рассуждений практиков, которые были связаны с периодом неопределенности распространения пандемии COVID-19.

Среди опрошенных психоаналитиков, которые продолжали практиковать во время карантина, около двух третей признали, что они в большей степени сфокусировались или сместились к определенным конкретным концепциям в своем теоретическом мышлении. Факт такого фокусировки или смещения не коррелировал с профессиональным опытом или статусом сертификации. Полученный анализ указанных психоаналитиками ценных концепций и теорий показал, что они касались двух основных вопросов: (1) как объяснить психическую реакцию человека или группы на пандемию COVID-19 и карантин в конкретном случае, и (2) каким образом психоаналитик может иметь дело с этой психической реакцией через собственную аналитическую позицию и интервенции. Практики преимущественно ссылались на теоретические позиции "Классического психоанализа", "Объектных отношений", а также на различные отдельные теории, такие как концепции горевания, тревоги, травмы, защитных механизмов и копингов, проявлений невротических конфликтов, проблематики Самости, комплексов, раннего травматического опыта и т.д. Кроме того, психоаналитики отметили некоторые ценные концепции по поддержанию аналитической позиции и определенные интервенции, например, значение их собственного анализа, а также контейнирования, холдинга и трансформации материала анализанта. Неожиданным оказалось, что 8\% практикующих психоаналитиков признали, что они сместили фокус внимания на некоторые неаналитические теории и концепции во время своей практики в контексте пандемии COVID-19, такие как когнитивные методы управления стрессом или стабилизацию. Это может 
DOI (Issue): https://doi.org/10.31108/1.2020.6.8

быть истолковано как с точки зрения интеграции психотерапии с целью получения лучших результатов, так и в подтверждение недостаточности психоаналитических теорий или вмешательств для некоторых важных психических феноменов, имеющих место во время периодов реальной травматизации и депривации, как пандемия.

Ключевые слова: COVID-19, классический психоанализ, объектные отношения, пандемия, психоанализ, психоаналитическая психотерапия.

\section{Мар'яна Великодна}

Кандидат психологічних наук, клінічний психолог, старший викладач кафедри практичної психології Криворізького державного педагогічного університету, сертифікований психоаналітик Украӥнської асоціації психоаналізу Європейської конфедерації психоаналітичних психотерапій, м. Київ (Украӥна)

\section{Галина Циганенко}

Кандидат психологічних наук, практичний психолог, стариий науковий співробітник, доцент кафедри психологї̈ Інституту підготовки кадрів державної служби зайнятості України, м. Київ (Украӥна)

\section{ЯКІ ТЕОРІЇ ТА КОНЦЕПЦЇ̈ ПСИХОАНАЛІТИКИ І ПСИХОАНАЛІТИЧНІ ПСИХОТЕРАПЕВТИ ВВА- ЖАЮТЬ ПОМІЧНИМИ У СВОЇЙ ПРАКТИЦ ПІД ЧАС РОЗГОРТАННЯ ПАНДЕМІЇ СОVID-19 В УК- PAÏHI?}

\section{АНОТАЦІЯ}

Неуникна напружена ситуація через пандемію COVID-19 змушує психоаналітиків стикатися з різноманітними питаннями, на які доводиться знаходити або винаходити власні відповіді. До деяких із цих питань психоаналітичні асоціації сформулювали чіткі вказівки. Однак певний унікальний випадок та обставини конкретної країни можуть не охоплюватися ними. Авторки статті вважають, що важливо досліджувати процеси, які спостерігають і теоретизують психоаналітики під час пандемії COVID-19. У цій статті представлені результати анонімного опитування психоаналітиків та психоаналітичних психотерапевтів $(\mathrm{n}=71) 3$ різних установ, асоціацій та теоретичних шкіл, яке було проведено онлайн через місяць карантину в Україні, для оцінки перших спостережень та міркувань практиків, які були пов'язані з періодом невизначеності щодо розгортання пандемії COVID-19.

Серед опитаних психоаналітиків, які продовжували практикувати під час карантину, близько двох тре-
Volume 6 Issue 82020

тин визнали, що вони більшою мірою сфокусувалися або змістилися до певних конкретних концепцій у своєму теоретичному мисленні. Факт такого фокусування чи зміщення не корелював 3 їх професійним досвідом чи статусом сертифікації. Отриманий аналіз вказаних психоаналітиками помічних концепцій та теорій показав, що вони стосувалися двох основних питань: (1) як пояснити психічну реакцію особи чи групи на пандемію COVID-19 та карантин у конкретному випадку, та (2) яким чином психоаналітик може мати справи 3 цією психічною реакцією через власну аналітичну позицію та інтервенції. Практики переважно посилалися на теоретичні позиції "Класичного психоаналізу", "Об'єктних відносин", а також на різноманітні окремі теорії, такі як концепції горювання, тривоги, травми, захисних механізмів та копінгу, проявів невротичних конфліктів, проблематики Самості, комплексів, раннього травматичного досвіду тощо. Крім того, психоаналітики відзначили деякі цінні концепції щодо підтримки аналітичної позиції та певні інтервенції, наприклад, значення їх власного аналізу, а також контейнерування, холдинг та трансформацію матеріалу аналізанта. Несподіваним виявилося, що 8\% практикуючих психоаналітиків визнали, що вони змістили фокус уваги на деякі неаналітичні теорії і концепції під час своєї практики в контексті пандемії COVID-19, такі як когнітивні методи управління стресом або стабілізацію. Це може трактуватися як 3 точки зору інтеграції психотерапії з метою отримання кращих результатів, так і в на підтвердження недостатності психоаналітичних теорій чи втручань для деяких важливих психічних феноменів, які мають місце під час періодів реальної травматизації і депривації, як пандемія.

Ключові слова: COVID-19, класичний психоаналіз, об’єктні відносини, пандемія, психоаналіз, психоаналітична психотерапія. 